\title{
AN EXPLORATION OF ANGER EXPRESSION IN INDONESIAN EFL LEARNING CONTEXT
}

\author{
Susiati \\ sus249@ums.ac.id \\ Universitas Muhammadiyah Surakarta
}

\begin{abstract}
This study investigates how the students of the Department of English Education, Universitas Muhammadiyah Surakarta express their anger in English as anger is an expression which relies on contexts. The students' conversations which contained anger expression were recorded. The expressions were analyzed based on pragmatic aspects: pragmalinguistic forms, communicative intention, context, and cultural background. The results showed that the students, mostly Javanese, did not use cursing or swearing forms in expressing anger in English which are typically in 'direct anger' and 'introductory anger'. Interestingly, although Javanese people are well-known as calm people, the students mostly rise their intonation in expressing their anger feeling in English.
\end{abstract}

Keywords: anger expression, pragmatic analysis, pragmalinguitic form, communication intention, cultural background

\begin{abstract}
ABSTRAK
Penelitian ini bertujuan untuk memaparkan bagaimana maha siswa dari program studi Bahasa Inggris, Universitas Muhammadiyah Surakarta mengekspresikan kemarahan mereka dalam bahasa Inggris sebagai suatu bentuk ekspresi kemarahan yang bergantung pada konteks. Percakapan siswa yang berisi ekspresi ekspresi kemarahan dicatat. Data dianalisis berdasarkan aspek pragmatis yang meliputi: bentuk pragmalinguistik, maksud komunikatif, konteks, dan latar belakang budaya. Hasil penelitian menunjukkan bahwa mahasiswa, yang umumnya orang besar Jawa tidak menggunakan bentuk kutukan atau sumpah dalam mengekspresikan kemarahannya dalam Bahasa Inggris; ini termasuk jenis 'kemarahan langsung' dan 'kemarahan pengantar'. Menariknya, meskipun orang Jawa yang dikenal sebagai orang yang tenang, maha siswa sebagian besar menaikkan intonasi mereka dalam mengekspresikan kemarahan mereka merasa dalam Bahasa Inggris.
\end{abstract}

Kata kunci: ekspresi kemarahan, analisis pragmatis, bentuk pragmalinguitik, maksud komunikasi, latar belakang budaya

\section{INTRODUCTION}

The expression of anger different languages used by people from different cultural backgrounds varies. English is learnt in all over the world because of its status as an international 
language. In Indonesia, as is probably also the case in other non-English speaking countries, English learners are interested to learn commonly used expressions in English, and anger is a feeling commonly expressed in English. The learners may simply translate their anger words in L1 based on their way of cultural background to English anger expressions. However, the challenge for learners of English as a foreign language is that one language cannot really deliver the same force of anger in another language (Chomsky, 2006).

However, other interpersonal expressions in English normally have templates such as greeting, thanking, apologizing. For example, Hello, Hi, How are you? for greeting, Thank you, Thanks, Many thanks for thanking, I apologize, I'm sorry, Would you forgive me? for apologizing (Matreyek, 2005). Whereas anger does not have fixed lexical templates in the same way. An expression will be difficult to categorize as anger if the context or situation is not known. It is difficult to identify whether an utterance is anger in isolation (Cosgrave, 2007). This may result in phrase books not containing templates of anger, especially in Indonesia (Cozier \& Kleinsasser, 2006).

Actually, there are other sources where English learners can learn anger expressions from. They may learn "angry words" on the internet such as I hate it when you're in a crotchety mood addressed to someone who is easily irritated (especially old people) (Learnex, 2014). However, not all people like expressing their anger directly (Konishi \& Hymel, 2014). The words hate and crotchety in the sentence are direct ways of saying anger. Furthermore, not all 'negative' colloquial words usually used in expressing anger are always used in angry way. For example, the word Shit cannot be generalized as an angry word in all sentences. When someone says Shit, that's cool man! to his/her close friend who has just bought a new car, it is not to show anger, but admiration. Conversely, when a boss says the same sentence to his/her staff who has not finished his/her work on time, the boss uses Shit to show his/her anger to the staff. Therefore, context or situation is very vital in expressing anger. This is a good example of Pragmatics to the study of everyday language.

Javanese is one regional language dominantly spoken on Java Island in Indonesia. Java is an Island where my teaching context takes place, and the students mostly come from the same place. Hence, I would like to seek how Javanese learners of English express anger in English. In order to exemplify the theoretical principles, therefore this essay will focus on pragmatics by presenting the pragmalinguistic forms. In addition, I will also show the communicative intention of the expressions since "a far more important source of difficulty in communication is that we often fail to understand a speaker's intention (Miller in Thomas, 1995: 18).

The rest of this essay will present Literature Review (Concept of Pragmatics, Pragmalinguistic Forms, Communicative Intention, Context, Cultural Background, Paralinguistic Features, Triggers for Anger and Studies on Anger Expression), Discussion, Conclusion, and Future Research.

\section{LITERATURE REVIEW}

\section{Concept of Pragmatics}

Pragmatics is a study of language meaning in which a function plays in language use (Olsen, 1988). Leech (1983:12) adds "pragmatics interacts with the grammar primarily through the semantics". Semantics is also a study of language meaning (Steiner \& Veltman, 1988), and some language learners may ask the distinction between pragmatics and semantics. Chierchia and McConnell-Ginet (2000) suggest that semantics deals with what expressions mean, while pragmatics covers what speakers mean in using the expressions. Green (1989) 
describes semantics as an interpretation of expressions that do not involve truth condition. Pragmatics is conversely defined as an interpretation of expressions that involve the context or situation behind the expressions (van Dijk, 1976; Thomas, 1995, Levinson, 2000). In short, pragmatics is a language-in-use study which seeks the meaning of an expression or why a speaker uses an expression in particular way. To conceal the meaning, context is very important to discuss. Context is where semantics does not deliberate.

Trosborg (2010) divides pragmatics into two aspects: pragmalinguistics and sociopragmatics. Pragmalinguistics focuses on knowledge of forms and strategies to convey particular illocutions, while sociopragmatics emphasizes on the use of the forms and strategies in appropriate context (Leech, 1983; Dippold, 2008). "Sociopragmatics is the interface of sociology and pragmatics" (Mirzaei, Roohani, \& Esmaeili, 2012:82) which may involve social values and behavior and hence needs a plenty of time to research. Therefore, this essay will focus only on pragmalinguistic knowledge by seeking the pragmalinguistic forms and the illocutionary force (Austin, 1962) or the communicative intention of the expressions (Thomas, 1995). In so doing, context and paralinguistic aspects are provided.

\section{Pragmalinguistic forms}

"Pragmalinguistic forms are the particular resources which a given language provides for conveying particular illocutions (Savic, 2014). Pragmalinguistic forms are also defined as the actual words uttered or Austin (1962) calls them locutions. I will consistently use the term "pragmalinguistic forms in this essay to emphasize that this essay is limited on pragmalinguistic rather than sociopragmatic aspect. Riley (1976) suggests that pragmalinguistic study areas are in "language functions rather linguistic structures, discourse, not grammar, the communicative act in context, not the sentence in isolation" (p.1). Hence, pragmalinguistic forms are the utterances expressed by a speaker to convey a certain intention in a particular language function within the context. Context will be elaborated separately from this part.

Pragmalinguistic forms are closely related to language functions. To make it clearer, there must be a language function in a pragmalinguistic form. For example, My name is Paul, This is Ann, Let me introduce myself (Matreyek, 2005) are the pragmalinguistic forms of the language function 'introduction'. I apologize, I'm sorry, Would you forgive me? (ibid.) are the pragmalinguistic forms of the language function 'apologizing'. Thus, implicitly or explicitly, a speaker's utterances contain a function, and this relates to the communicative intention (Thomas, 1995) or force or illocution (Austin, 1962).

\section{Communicative Intention}

Communicative intention has similar terms such as force, illocutionary force, illocutionary act, pragmatic force, speech act which means a speaker's purpose of expressing an utterance (Thomas, 1995). I will consistently use communicative intention in the remaining of this essay because the term 'intention' is explicitly stated to easily remember that it means an intention or purpose. Thomas (ibid.) calls communicative intention "the second level of speaker meaning" (p.18) which the first one is "the utterance meaning" (p.16) which examines the meaning from literal words. How the utterance meaning works is similar to semantics because the focus is on the hearer's meaning, while communicative intention focuses on the speaker's meaning (Criticism, 2004). The problem of the utterance meaning lies on "the fact that the original lexical meaning of an expression is not a good guide to the speaker's intention in employing that expression" (Thomas, 1995:17). It may be also difficult to interpret such expression as anger feeling by merely seeing the words used taken out of context since sometimes anger, even more often, is expressed indirectly (Konishi \& Hymel, 2014). It means 
anger feeling is frequently expressed in "non-angry words". Therefore, context plays very important role in determining the communicative intention.

\section{Context}

Halliday (1991) suggests that context is events that accompany a person when he/she speaks or writes. Celce-Murcia and Olsthain (2000) defines context in more specific as all nonlinguistic and nontextual factors which affect spoken or written communicative interaction. Celce-Murcia and Olsthain's definition seems clearer on this case.

To interpret the meaning of an expression, words may not be enough. As I have mentioned in the introduction section, the word Shit normally known as a word for expressing anger, cursing, or swearing does not always mean the same thing in another context. Context plays very important role in identifying the intention of an expression (Taguchi, 2009). In this essay, I would limit the context in the scope of situations built, the relationships among speakers and the cultural background in the interactions, not the context referring to widening set of factors such as behavior, gender, sexual identities, institution (Gee, 2005) as in the sociopragmatics area of study.

Context is important to interpret anger feeling in an expression. First, as anger feeling is frequently expressed indirectly (Konishi \& Hymel, 2014), the situation accompanying the interaction can help identify whether an expression is an anger feeling. Gee (2005) calls this a 'situated meaning'. Second, the relations among speakers and hearers are also the keys for a hearer to understand a speaker's intention whether or not they share knowledge (CelceMurcia \& Olshtain, 2000). Third, cultural background is also important to reveal a context. Holliday (1999) distinguishes culture into two paradigms: large culture and small culture. Large culture entails ethnic, national and international differences, while small culture refers to social groupings or activities regardless the differences previously mentioned (Holliday, ibid.). Because of arising an ethnic culture in Java, this essay will refer to the large culture paradigm which I, then, write culture only. The discussion on culture will be provided in the next sub-section.

\section{Cultural Background}

In this part, I will describe how Javanese people generally express their emotions. In Java, particularly in Yogyakarta and Solo - Solo is the region where my teaching and learning context is located or the data in the interaction were taken - people have refined, calm and smooth personality which is called alus in Javanese language compared to other Indonesians (Berman, 1999). This is due three valuable characteristics of the culture, namely ikhlas (a detachment from the material world), sabar (the absence of eagerness, impatience and passion), and trima (the acquiescence to the inevitability of fate, class, hierarchy, gender and event (Geertz in Berman, 1999). These three characteristics lead to avoidance of potential disharmony (ibid.). Anger seems very rarely expressed or expressed indirectly by Javanese people because "direct disclosure of one's personal innermost feelings is rarely done by use of Javanese" (Wolff \& Peodjosoedarmo, 1982:64). However, this does not mean that Javanese people never convey their anger feeling, but their way is different, not using cursing or swearing words (Berman, 1999).

\section{Paralinguistic Features}

To identify what intention a speaker means, it may not be accurate to simply look at what is uttered. In order to work out the intended meaning, a hearer can use the speaker's intonation or word stress, for example, which is a part of paralinguistic features (Riley, 1976; Thomas, 
1995). Paralinguistic phenomena occur in the utterances of anger. Lyons (1999) has already pointed out that the term 'paralinguistic' (together with 'paralanguage') is used in a variety of different ways in the literature. It includes non-prosodic vocal phenomena such as variations of pitch, loudness, duration, and non-vocal phenomena such as eye-movements, head-nods, facial expressions, gestures, body-posture. This essay focuses on the non-prosodic vocal phenomena since the data are audio recording. In addition, Roach (1987) suggests that anger is normally expressed in rise intonation. This suggestion may be for generally speaking regardless to the ethnic, national and international differences.

\section{Triggers for anger}

Cosgrave (2007: 482) divides the triggers for anger into four types: (1) Frustration of a need or a want, e.g., missing a bus or a train, being blocked in completing some project or task that one is absorbed in; (2) Suffering some injustice or noticing others being unjustly treated, e.g., being passed over for promotion, having precious property stolen, seeing the weak being exploited by the powerful; (3) Experiencing a threat to one's self-esteem, e.g., being insulted, being considered a failure, having one's good name impugned; (4) Being injured physically, e.g., being assaulted, or being injured by a drunken driver.

Indeed, a trigger, for anger on this case, is not something different from situation (Cosgrave, ibid.), and may be prompt to what Gee (2005) calls a situated meaning. Hence, I will not restrict the triggers for anger on Cosgrave's idea. Other triggers are possible to interpret an anger expression.

\section{Studies on Anger Expression}

Marjayanti (2010) studies a similar topic entitled "Expression of Anger Uttered by Characters in Drama Manuscripts (Pragmatics Approach)". She uses implicature to seek the anger expressions. The drama are all based on Western culture, and the result shows that requesting, warning and threatening are the common implicatures used to express anger in the drama. What is relevant from Marjayanti's study to this essay is that Marjayanti uses pragmatics approach where context plays important role, as is in implicature. In addition, this study examines drama manuscripts as this essay does although I will present the Indonesian EFL (English as a Foreign Language) students' role plays' manuscripts. However, Marjayanti's study is taken from Western drama, while I will discuss the students with Javanese cultural background in Indonesia.

In different context, Berman (1999) studies how Javanese women speak of emotion in Indonesia. This study takes place in Yogyakarta and Solo, two regions in Java Island as she suggests as the regions with the most refined people of all Indonesians. She scrutinizes how Javanese women reveal their emotion, including anger, in a dignity situation, and social power is her main research. The result shows that the women speak in three Javanese refined levels namely ngoko (less polite/general people language), kromo (medium), kromo inggil (most polite normally used by people living in Keraton - a Javanese palace). She also infers that even the women use ngoko to speak their emotion, it is generally considered more polite compared to those from other parts of Indonesia. The cultural background is very relevant to this essay that is Javanese students in Solo. However, this essay will not limit the speakers on certain gender, but both male and female students participate.

\section{FINDINGS AND DISCUSSION}

In this essay, I will pick out two audio recordings of some students' conversations. The 
conversations were recorded in the classroom in the anger expression classroom meeting. The students were interacting in group which each group generally consisted of two to three members. Messy grammars occur a lot, but for the sake of naturalness, I will not correct them. The focus is, again, on pragmatic aspects, not on Grammar.

Conversation 1

(On Telephone_the Rin's phone is ringing)

A1: $\overrightarrow{\text { Hello, Umi. }}$

B1: $\overrightarrow{\text { Hello, Rin. Is my book still with you? }}$

A2: Yes, Umi.

B2: Bring my book tomorrow, $\overrightarrow{\mathrm{Ok}}$

A3: $\overrightarrow{\mathrm{Ok}}$.

(After Tomorrow)

B3: Hi, Rin. Where is my book?

A4: I'm so sorry Umi. I forget put down your book.

B4: Ouch... $\overrightarrow{\text { Rina }} \overrightarrow{\text { the day after tomorrow we have exam. So how I learn? }}$

A5: $\overrightarrow{\text { I'm so sorry Umi. }}$

B5: I don't want to know. You must bring the book tomorrow. Ok?!

First of all, it is difficult to decide which pragmalinguistic forms of anger and communicative intention of the conversation are without knowing the context. Therefore, context will be explained in the analyses prior to the other aspects. This is the proof of how context is the main key of a pragmatic analysis especially to identify an expression intention (Taguchi, 2009). The context comprises situation (Gee, 2005), relations among speakers (Celce-Murcia \& Olshtain, 2000), Javanese cultural background (Berman, 1999; Wolff \& Peodjosoedarmo, 1982) and paralinguistic features (Riley, 1979; Thomas, 1995; Lyons, 1999).

This conversation is situated by two speakers where B rings A to ask confirmation whether B's book is still borrowed by A and at once to remind A to return B's book a day after. On the second day, B met A to ask the book, but A forgets to bring B's book. Then, B's emotion seems to arise. This is the situation during the conversation or Gee (2005) describes as a situated meaning.

The relation of the two speakers is friends studying the same subject because they will face an exam together 'tomorrow' seen from the utterance Rina the day after tomorrow we have exam. Not to confuse, after tomorrow the students mean is tomorrow, a day after today. The relation is also as close friends since B rang A a day before to remind A to bring B's book. Here, the two speakers have shared the same exam, a reference book used in the exam, and the telephone number each other. Celce-Murcia and Olshtain (2005) calls these shared knowledge. 
Furthermore, B seems to feel angry with A because A forgets to return B's book. B's expression ouch is rarely used in Javanese culture. It means B has got very angry with A. In addition, the day after tomorrow we have exam. So how I learn?, I don't want to know. You must bring the book tomorrow. Ok?! are the expressions showing anger. First, this is very typical how Javanese people convey anger. None of the expressions contain cursing or swearing words which are still considered 'polite anger' (Berman, 1999). Second, none of the expressions contain direct anger. B uses rhetoric questions to urge A to return B's book. This is aligned to Wolff and Poedjosoedarmo (1982) that "direct d disclosure of one's personal innermost feelings is rarely done by use of Javanese" (p.64). B expresses anger indirectly.

To prove more, a paralinguistic feature exists in the conversation. Rising intonation can be an indicator of an utterance considered an anger expression. Roach (1987) states that anger is normally expressed in rise intonation. However, I will not generalize that all rising intonation expressions show anger. It depends on the situation in an interaction. B1 uses rising intonation because it is a question as well as B3. A question is normally expressed in rising intonation. However, rising intonations in B4 and B5 ended with question marks are rhetoric questions which do not mean asking questions. B uses requesting strategy to express her anger. This is in line with Marjayanti's (2010) result of study that requesting is commonly used in expressing anger.

Because the context has been completely analyzed, I will come to the communicative intention and pragmalinguistic forms. From the elaboration of context, we can see that the intention of B4 and B5 is to express anger, not asking a question although the expressions are ended with question marks. Therefore, the pragmalinguistic forms of anger expression used by the Javanese students in this context are Ouch...Rina the day after tomorrow we have exam. So how I learn? and I don't want to know. You must bring the book tomorrow. Ok?!

\section{Conversation 2}

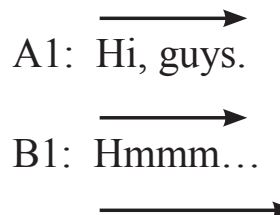

A2: What's wrong with you?

B2: Never mind. Do you feel wrong?

A3: No, I don't.

B3: Where did you go yesterday?

C1: We were waiting for you for a long time in the park.

A4: Why do you waiting for me?

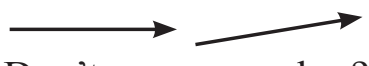

B4: Don't you remember?

A5: Remember what? 
B5: We have team work.

A6: Oh, sorry. I forgot. Yesterday I went with my boyfriend.

B6 \& $\mathrm{C} 2$ : $\overrightarrow{\text { What?! }}$

The situation of this conversation is different from conversation 1 in terms of the topic of conversation. This interaction tells a story about a team work of three friends. However, both conversations are similarly telling about a colleague who breaks his/her promise to his/her friends. In this case, A broke her promise to come to the team work a day before. This situation shows the context of this conversation (Gee, 2000).

The relation of the three friends is as close friends. There are two reasons. First, the greeting Huy guys shows informality in the conversation. It means they have shared friendliness before. Second, Do you feel wrong? responding to What's wrong with you? sounds cynical because a question is answered back with a question and with the same question. It seems not happening in a group whose members are all or some are new. It means they have shared knowledge of one another's characteristics. Therefore, shared knowledge affects the relation among students (Celce-Murcia \& Olshtain, 2000).

This conversation shows more typical Javanese culture that Javanese people do not like bluntly express their innermost feelings to public (Wolff and Poedjosoedarmo, 1982). B is disappointed with A because A did not come to the team work a day before, but B prefers to ask back to A instead of saying the true feeling. It is similar to the expressions of B3, C1 and B4 until B5 expresses the true reason. To attain B5, there are three 'introductory anger'.

Seen from paralinguistic features, conversation realizes richer features. I use straight arrow to mark falling intonation and rising arrow to mark rising intonation in both conversations. In this conversation, anger is not consistently expressed in rising intonation. $\mathrm{C} 1$ uses falling intonation, but the content of words is anger based on the situation. C1 uses for a long time to emphasize that $\mathrm{B}$ and $\mathrm{C}$ are disappointed because $\mathrm{A}$ did not come to the teamwork. Therefore, this is not in line with Roach (1987) who suggests that anger is normally expressed in rising intonation. Meanwhile, the expressions used by B2, B3, B4, B6 and C2 are requesting (Marjayanti, 2010) or rhetoric questions which show anger. B6 and C2 together say What?! in rhetoric, exclamatory and stressed word. This shows surprise which means the reason given by A may not make any sense.

From the context having been elaborated, it can be drawn results that the intention of $\mathrm{B} 2$ B3, B4, B6, C1 and C2 is to display anger to A. Hence, the pragmalinguistic forms of how the Javanese students express anger in conversation 2 context are Never mind. Do you feel wrong?, Where did you go yesterday?, We were waiting for you for a long time in the park., Don't you remember?, and What?!

\section{CONCLUSION}

The pragmalinguistic forms used by the Javanese students are typically Javanese culture which do not contain cursing or swearing words because Javanese people are famous with their refinement. Hence, 'indirect anger' and 'introductory anger' color the way the students express their anger. Interestingly, although Javanese people are well- known as calm people, the students mostly rise their intonation in expressing their anger feeling. However, there is one anger expression in falling intonation in conversation 2. It means, not to generalize, anger 
is normally expressed in rising intonation (Roach,1987) even by calm and smooth personality people.

This essay focuses only on pragmalinguistic forms and communicative intention of anger expression. The data can be widely analyzed with pragmalinguistic failure from the pragmalinguistic forms of anger expression emphasizing on cross-cultural expression meaning. It is also interesting to seek the sociopragmatic aspects such as how different gender of Javanese students express their anger, more social value coverage, and behavior of Javanese people for a future research.

\section{REFERENCES}

Austin, J.1. 1962. How to Do Things with Words. Oxford: Oxford University Press.

Berman, L. 1999. Dignity in Tragedy: How Javanese Women Speak of Emotion. In G. Palmer and D. Occhi (eds.) Languages of Sentiment (pp. 65-106). Philadelphia: John Benjamins.

Celce-Murcia, M. and Loshtain, E. 2000. Discourse and Content in Language Teaching: A Guide for Language Teachers. Cambridge: Cambridge University Press.

Chierchia, G. and McConnell-Ginet, S. 2000. Meaning and Grammar -- An Introduction to Semantics, 2nd ed. Cambridge: MIT Press.

Chomsky, N. 2006. Language and Mind. Cambridge: Cambridge University Press.

Cosgrave, B. 2007. Understanding Anger. Maynooth: The Furrow. Available from: http://www.jstor.org/stable/27665595 [Accessed: April 11 ${ }^{\text {th }}, 2015$ ].

Cozier, N. and Kleinsasser, R.C. 2006. Home Country Teachers' Advice to Non-Home Country Teachers. London: SAGE Publications. Available from: http://RELC.sagepub. com [Accessed: April 13 $\left.{ }^{\text {th }}, 2015\right]$.

Criticism. 2004. Available from: http://www.criticism.com/linguistics/semantics-vspragmatics.php [Accessed April 18 $\left.{ }^{\text {th }}, 2015\right]$.

Dippold, D. 2008. Reframing Ones Experience: Face, Identity, and Roles in L2 Argumentative discourse. In M. Putz \& J. A. Neff-van (Eds.). Developing Contrastive Pragmatics. Interlanguage and Cross-cultural perspectives (pp. 131-154). Berlin: Mouton de Gruyter.

Gee, J.P. 2005. An Introduction to Discourse Analysis: Theory and Method. London: Routledge.

Green, G.M. 1989. Pragmatics and Natural Language Understanding. New Jersey: Lawrence Erlbaum Associates.

Holliday, A. 1999. Small Cultures, Applied Linguistics, 20(2), 237-264.

Konishi, C. and Hymel, S. 2014. An Attachment Perspective on Anger among Adolescents. Detroit: Wayne State University Press. Available from:http:// www.jstor.org/stable/10.13110/merrpalmquar1982.60.1.0053 [Accessed: April 11 ${ }^{\text {th }}$, 2015].

Learnex. 2014. Available from: http://learnex.in/vocabulary-to-express-anger-in-english/ [Accessed April 17 ${ }^{\text {th }}, 2015$ ].

Leech, G.N. 1983. The Principles of Pragmatics. London: Longman. Levinson, S.C. 1983. 
Pragmatics. Cambridge: Cambridge University Press. Lyons, J. 1999. Semantics. Cambridge: Cambridge University Press.

Marjayanti, D. 2010. Expression of Anger Uttered by Characters in Drama Manuscripts (Pragmatics Approach), MUP, 10(2), 18-27.

Matreyek, W. 2005. Communicating in English: Examples and Models. In Q. Masykuroh \& N. Hidayat (eds.) Situational Communications in English. Surakarta: Muhammadiyah University Press.

Mirzaei, A., Roohani, A. \& Esmaeili, M. 2012. Exploring Pragmalinguistic and Sociopragmatic Variability in Speech Act Production of L2 Learners and Native Speakers, JTLS, 4(3), 79102.

Olsen, S.E. 1988. Psychopathology, Interaction, and Pragmatic Linguistics. In J.L. Mey (ed.) Pragmalinguistics: Theory and Practice. The Hague: Mouton Publishers.

Riley, P. 1979. Towards a Contrastive Pragmalinguistics, $\mathrm{PsiCl}, 10,57-79$.

Roach, P. 1987. English Phonetics and Phonology. Cambridge: Cambridge University Press.

Savic, M. 2014. Politeness through the Prism of Requests, Apologies and Refusals (a Case of Serbian EFL Learners). Newcastle: Cambridge Scholars Publishing.

Steiner, E. H., \& Veltman, R. (eds.) 1988. Pragmatics, Discourse and Text: Some systemically Inspired Approaches. London: Pinten.

Taguchi, N. (Ed.). 2009. Pragmatic competence. New York, Berlin: Mouton de Gruyter. Thomas, J. 1995. Meaning in Interaction: an Introduction to Pragmatics. London: Longman.

Trosborg, A. (Ed.). 2010. Pragmatics across languages and cultures. Berlin: Mouton de Gruyter.

Van Dijk, T.A. 1976. Pragmatics, Presuppositions and Context Grammars. In J. Schmidt (ed.) Pragmatics 2. Munchen: Wilhelm Fink Verlag.

Wolff and Peodjosoedarmo. 1982. Anthropological Linguistics. Bloomington: Indiana University Press. 